\title{
Experimental Agriculture
}
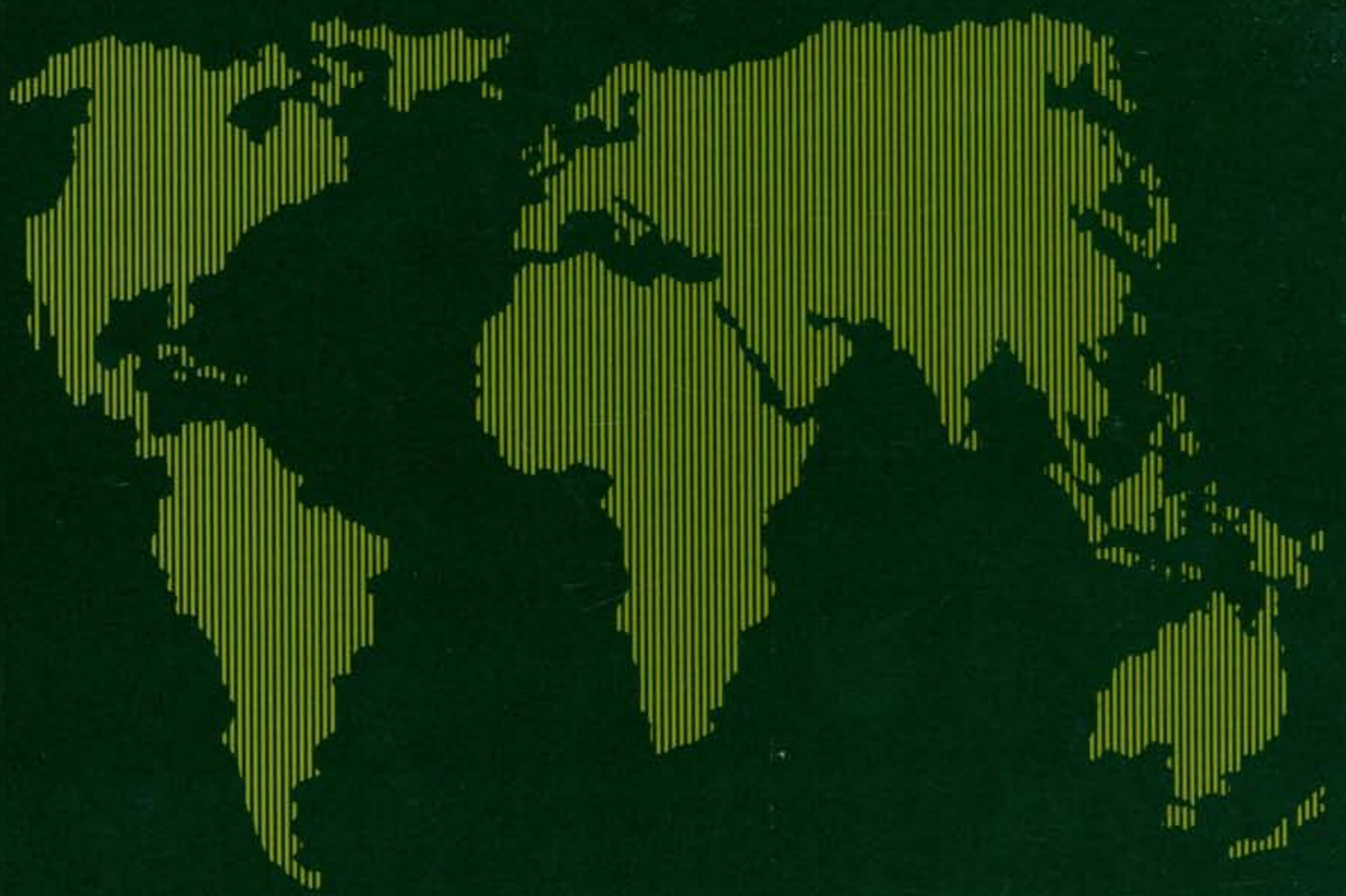

Tropical regions, Farming systems Plantation crops, Sustainability 
Editor: Dr F. G. H. Lupton, 1 The Knapp, Haslingfield, Cambs. CB3 7JH

Managing Editor: Dr Susan Carr

Book Review Editor: Professor J. M. Hirst

\author{
Editorial Board \\ DR M. H. ARNOLD (Chairman)
}

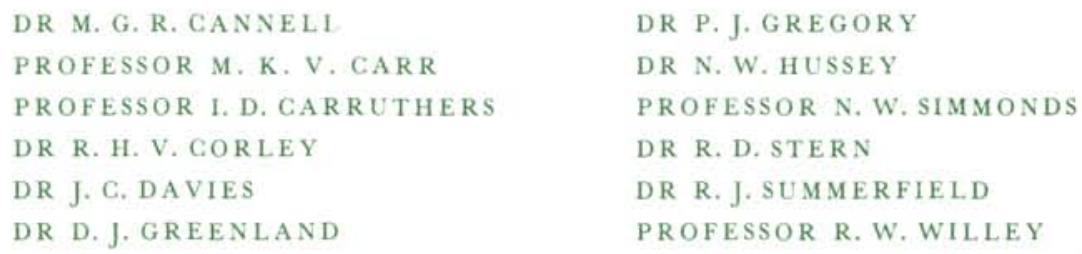

Overseas Correspondents

PROFESSOR J. L. MONTEITH, ICRISAT DR M. P. COLLINSON, CGIAR DR P. J. M. COOPER, ICARDA

Experimental Agriculture is the successor of the Empire Journal of Experimental Agriculture, which was founded in 1933. It publishes the results of analytical studies of the agronomy of crops, and particularly of the food, forage and industrial crops of the warmer regions of the earth. It is especially concerned with experimental work, conducted in the field and designed to explain agronomic results in biological and environmental terms. Papers on plant breeding may be accepted if their interest is primarily agronomic; submissions from researchers using artificial, more-or-less controlled or protective environments, may also be accepted. However, the main emphasis is on measurement and experimentation in the field, associated in appropriate cases with survey methods. The journal also publishes accounts of new experimental techniques, new methods in experimental crop production, and critical discussions of specific problems arising in countries where agricultural production is developing rapidly. Reviews of particular fields of agronomy, or of agronomic research methods, will be commissioned from time to time by the Editor, who welcomes suggestions of appropriate topics. Experimental Agriculture (ISSN 0014 4797) is published four times a year in January, April, July and October.

Orders, which must be accompanied by payment, may be sent to any bookseller or subscription agent or direct to the publisher: Cambridge University Press, The Edinburgh Building, Shaftesbury Road, Cambridge CB2 2RU, or in the USA and Canada, The Journals Department, 40 West 20th Street, New York, NY 10011, USA. The subscription price of volume 26, 1990, is $£ 62$ net (including postage) for a volume (US \$144 in the USA and Canada), payable in advance; separate parts cost $f 17$ net or $\$ 39$ each (plus postage). Second class postage paid at New York, NY and at additional mailing offices. POSTMASTER : send address changes in the USA and Canada to Experimental Agriculture, Cambridge University Press, 110 Midland Avenue, Port Chester, New York, NY 10573.

Back Volumes. Inquiries for Vols. 1-32 of The Empire fournal of Experimental Agriculture should be addressed to Wm Dawson \& Sons Ltd, Cannon House, Folkestone, Kent. Previously published parts of Experimental Agriculture are available from Cambridge or the American Branch of Cambridge University Press. 